\title{
Palustrine sedimentation in an episodically subsiding basin: the Miocene of the northern Teruel Graben (Spain)
}

\author{
A.M. Alonso-Zarza *, J.P. Calvo \\ Departamento Petrología y Geoquímica, Fac. CC. Geológicas, Universidad Complutense, 28040 Madrid, Spain
}

\begin{abstract}
Lacustrine deposits form most of the sedimentary record accumulated throughout the Miocene in the northern part of the Teruel Graben, a landlocked basin situated in NE Spain. Three main stratigraphic units (Units I-III) spanning Late Vallesian to Late Turolian in age, are distinguished in the area. The two former units comprise mainly carbonate lacustrine deposits that were deposited in a palustrine or a more permanent but shallow lacustrine setting, the latter being related mainly to periods of lake expansion under more humid and cooler climatic conditions. In contrast, deposition of Unit III, characterised by gypsiferous lacustrine sediments in central parts of the basin, reflects the influence of source rocks of evaporitic nature (Upper Triassic formations) that were emplaced by diapiric uplift in the eastern margin during the Middle Turolian. Carbonate lake sediments belonging to Units I and II consist of four main lithofacies associations: (a) distal-alluvial lake margin deposits; (b) lacustrine carbonates and pedogenically modified lacustrine carbonates; (c) carbonate fill channels; and (d) organic-rich marlstone and carbonate (marshes). Lithofacies association (a) shows typically a sequential arrangement formed, from bottom to top, of red mudstone, carbonate palaeosols and biomicrite beds (sequence type la). These sequences are interpreted as a result of slow but continuous aggradation of the floodplain areas and subsequent rise of the water table, probably reflecting equilibrium between subsidence and sedimentation. Lithofacies association (b) consisting of biomicrite beds passing upward into palaeosols (sequence type $1 \mathrm{~b}$ ) is thought to be caused by marked pulses of tectonic subsidence that created the accommodation space required for fast development of a carbonate lake. Carbonate fill channels, showing erosive lower surfaces dig out on previous channels, marsh deposits and/or lacustrine carbonates, exhibit well-developed prismatic structure at their bed tops. The sequential arrangement suggests similar tectonic constrains than the envisaged for lithofacies $1 \mathrm{~b}$. The comparison of depositional styles of the lake systems with the palaeoclimatic evolutionary pattern of the basin throughout the Miocene indicates that the combined effect of tectonism, climate and source rock played a major role in the stratigraphic framework of the basin during this period.
\end{abstract}

Keywords: climate; lacustrine deposits; Miocene; palaeosols; tectonics; Teruel Graben

\footnotetext{
* Corresponding author. Fax: 34-915442535..

E-mail address: alonsoza@eucmax.sim.ucm.es (A.M. Alonso-Zarza)
} 


\section{Introduction}

Palustrine carbonates can develop under several tectonic and climatic contexts (Platt and Wright, 1991). Climate seems to be one of the major controls on carbonate deposition in lacustrine environments (Camoin et al., 1997), being semi-arid to sub-humid climates the more favourable for the development of palustrine conditions (Platt and Wright, 1992), but hydrology and source rock are also important as they supply water, calcium and bicarbonate. Tectonism is considered an important factor that controls the morphology of the lake basins and also the rate of clastic supply to the shallow lakes (Nickel, 1985; Gierlowski-Kordesch, 1998; De Wet et al., 1998). Palustrine deposits are commonly recognised in relatively stable basins, or in periods of tectonic quiescence when the adjacent alluvial-fluvial systems are less active inhibiting clastic supply (Molenaar and De Feyter, 1985; Platt, 1992). However, palustrine carbonates do also occur in subsiding basins, as in the Lower Cretaceous of the Serranía de Cuenca in central Spain (Gierlowski-Kordesch et al., 1991; FregenalMartínez, 1998) and other formations of similar age in the Iberian Ranges (Soria, 1997). In these active subsiding basins, the sequence of sedimentary-pedogenic processes which occur combined in palustrine environments (Freytet and Plaziat, 1982; Freytet, 1984) may vary in response to the differential movements of the lake floor. On the other hand, in relatively stable and slowly aggrading sedimentary basins, such as the Madrid Basin, central Spain, the development of shallow lakes is gradual on distal fan/floodplain deposits (Sanz et al., 1995), and the progressive rise of the water table results in a complex sequence in which it is difficult to differentiate between carbonates formed through precipitation within a soil or within a shallow water body. In contrast, in palustrine environments where the basin floor is unstable due to marked tectonic subsidence pulses, the rise of water level may be very rapid and abrupt transitions from alluvial to lake deposits are expected.

The aim of this paper is to analyse if palustrine sequences may be indicative of the different tectonic regimes that control the rate of rising- lowering of the water table. The study area, the northern Teruel Graben, comprises a variety of palustrine sequences and facies that makes it suitable for this purpose. The palustrine deposits are very varied including: biomicrites; tufas; carbonate-filled channels; mottled and desiccated micrites and bioturbated micrites; amongst others. In this study we intend to show that not only the occurrence and location of the palustrine facies but also their arrangement were clearly controlled by the morphology and relatively movements of the lake floor.

\section{Geological setting}

The Teruel Graben, also named Teruel Fosse (Mein et al., 1990) is located on the northeastern side of the Iberian Peninsula (Fig. 1). The basin is oriented NNE-SSW and occupies an area of ca. $100 \mathrm{~km}$ in length and $15 \mathrm{~km}$ in width. It is filled by a rather complete Neogene succession reaching up to $500 \mathrm{~m}$ in thickness (Moissenet, 1983, 1989). The basin is regarded as a half-graben bounded by several en échelon NNE-SSW normal faults which are mainly located in the eastern part of the basin (Anadón and Moissenet, 1996). Hangingwall subsidence is westwards of the faults while footwall uplift is eastwards of the faults. The formation of the basin is envisaged as related to the extensional movements linked to the rifting of the western Mediterranean during the Miocene (Anadón et al., 1989; Roca, 1996).

In the northern part of the Teruel Graben (Teruel-Alfambra region) (Figs. 1 and 2), the Neogene succession is bounded by siliciclastic and evaporitic formations of Triassic age as well as Jurassic carbonate deposits. Palaeogene formations also occur in some parts of the basin margins, especially to the north of the Teruel Graben. The Neogene deposits in the central and western areas of the basin overlie unconformably the Triassic, Jurassic and Palaeogene formations, but in the eastern margin of the basin, as observed in the Tortajada area the two lowest Miocene Unit are thrusted by the evaporitic Triassic Formations. The oldest Neogene deposits have been dated as 


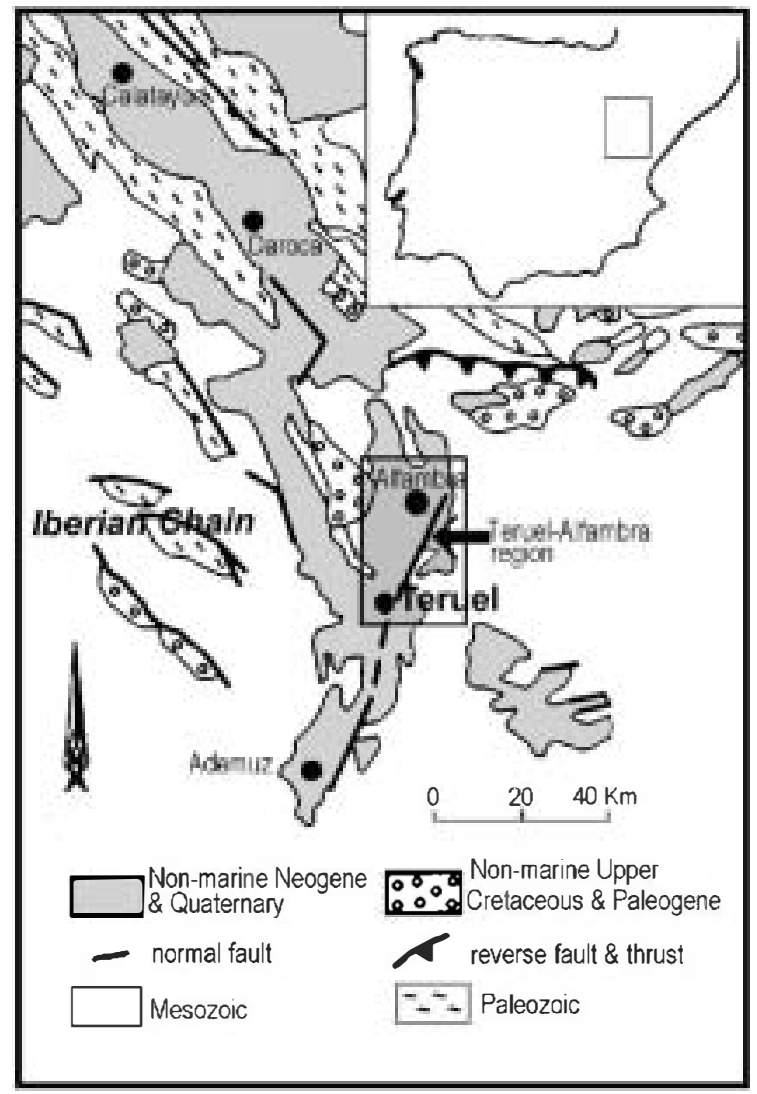

Fig. 1. Situation of the Teruel Graben in the NE Iberian Peninsula. The Neogene deposits of study area (in the square) are bounded mostly by Mesozoic formations.

Lower Aragonian (van Dam, 1997). However, most of the basin fill sequence cropping out in the region comprises sediments ranging from Lower Vallesian to Pliocene in age (Fig. 3). The dating method is mainly based on mammal faunas which are widely distributed across the basin (Alcalá, 1994; van Dam, 1997). The majority of the mammal localities are found in stratigraphic superposition and various key sections have provided the basis for magnetostratigraphic analysis (Garcés et al., 2000; van Dam et al., 2000) which allows correlation of the mammal succession to the geomagnetic polarity time scale (GPTS) (van Dam, 1997).

The Neogene sedimentary record of the northern area of the Basin comprises four stratigraphic
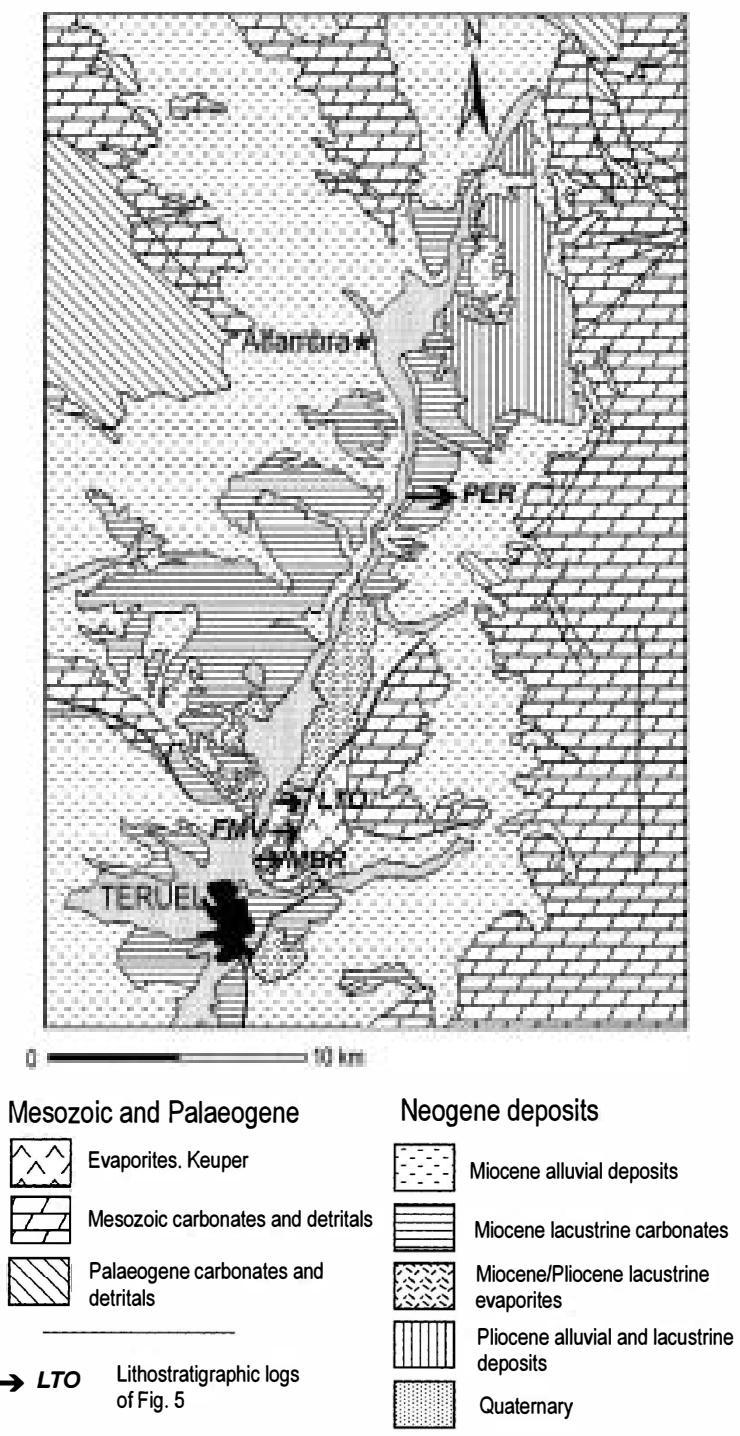

Fig. 2. Geological map of the study area with location of the logs shown in Fig. 4.

units. The three lower units are Miocene in age, while the uppermost one belongs mostly to the Pliocene (Fig. 3). The lowermost unit (Unit I, Lower to Upper Vallesian) shows a maximum thickness of $50 \mathrm{~m}$ and is formed of coarse red clastic facies in both the eastern and western margins of the basin; towards the central areas of the basin, these deposits grade into a sequence composed of fine clastic sediments at the base and lacustrine carbonates at the top. Unit II (Upper 


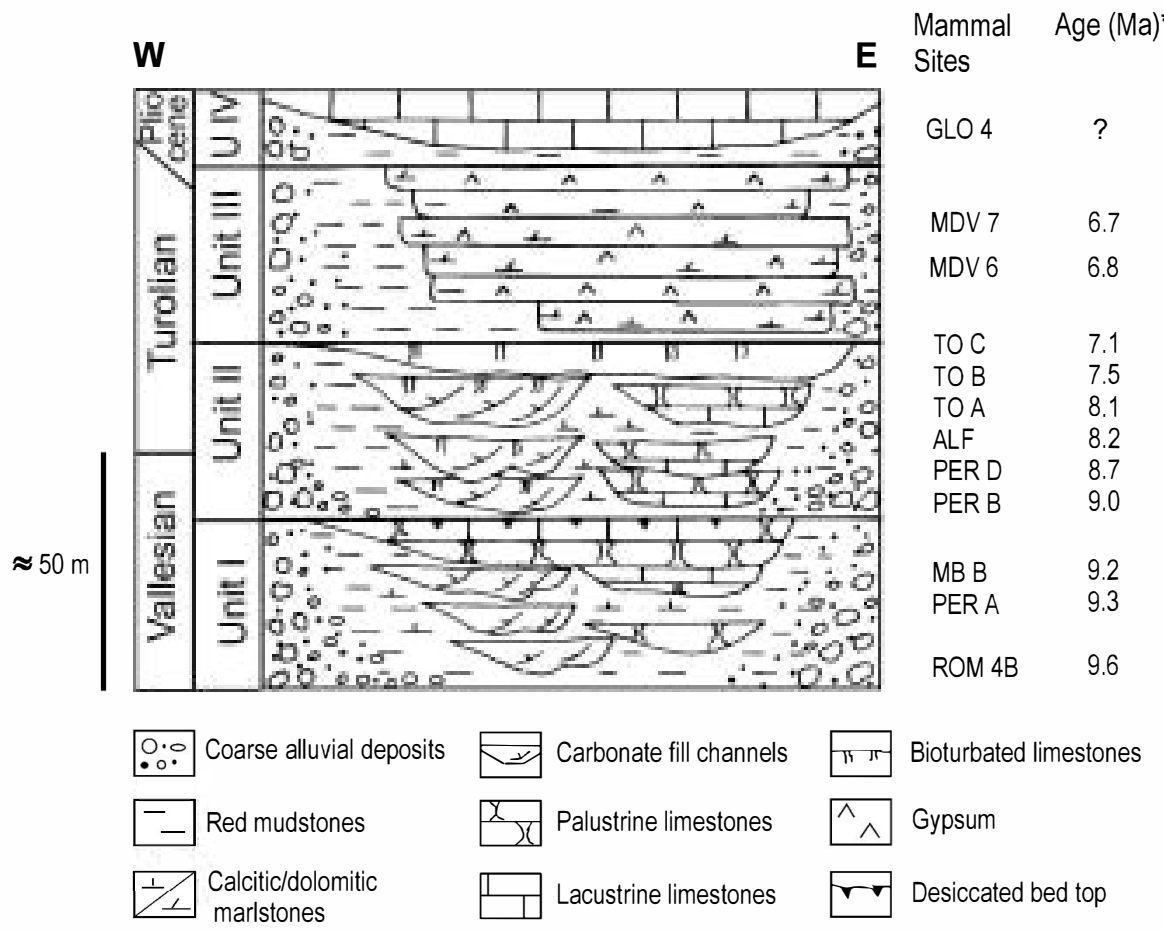

Fig. 3. Stratigraphy of the Neogene sedimentary record of the northern Teruel Graben with situation and age of selected mammal sites. *Numerical data after van Dam (1997) through the study or $>100$ micromammal sites.

Vallesian to Middle Turolian) begins with red and green terrigenous deposits that sharply overlie the carbonates of the underlying unit. The lateral and vertical facies arrangement is similar in both units but carbonates of Unit II lie closer to the basin margins (Fig. 3). Moreover, the boundary between the two units is interpreted as an abrupt progradation of coarse-grained alluvial deposits (gravels) on sandstones and/or mudstones of Unit I in marginal areas of the basin. Both clastic and carbonate sediments forming the top of Unit II are slightly folded, revealing active tectonism soon after the deposition of this unit. Classically, the carbonates that occur in the aforementioned units have been referred to as the Alfambra Formation (van de Weerd, 1976) and the reddish alluvial facies of both units have been given several names such as Peral Formation, Tejares Formation, Los Monotos Series (Godoy et al., 1983; Moissenet 1983; Alcalá, 1994). More recently, Alonso-Zarza et al. (2000) have grouped these terrigenous deposits as Red Clastic Facies.
Unit III represents a drastic change in the distribution of the sedimentary environments of the basin. This unit, which encloses the so-named Tortajada Formation (van de Weerd, 1976), is mostly composed of gypsum beds that grade laterally, towards the west and south, into red siliciclastic deposits and locally include marlstone and dolomitic carbonates (Fig. 4). As observed in the vicinity of the Tortajada village, the evaporitic sediments, reaching a maximum thickness of $140 \mathrm{~m}$, display a well-defined cyclic depositional pattern. Towards the north of the basin the gypsum deposits change laterally into carbonate successions. The age of this unit is Middle and Late Turolian.

Unit IV is at the top of the Neogene sections throughout most of the basin. This unit comprises a variety of siliciclastic, carbonate and local gypsum facies grouped into the Escorihuela Formation, which reaches up to $40 \mathrm{~m}$ in thickness. The sediments belonging to this unit have been studied in detail by Moissenet et al. (1990) and 

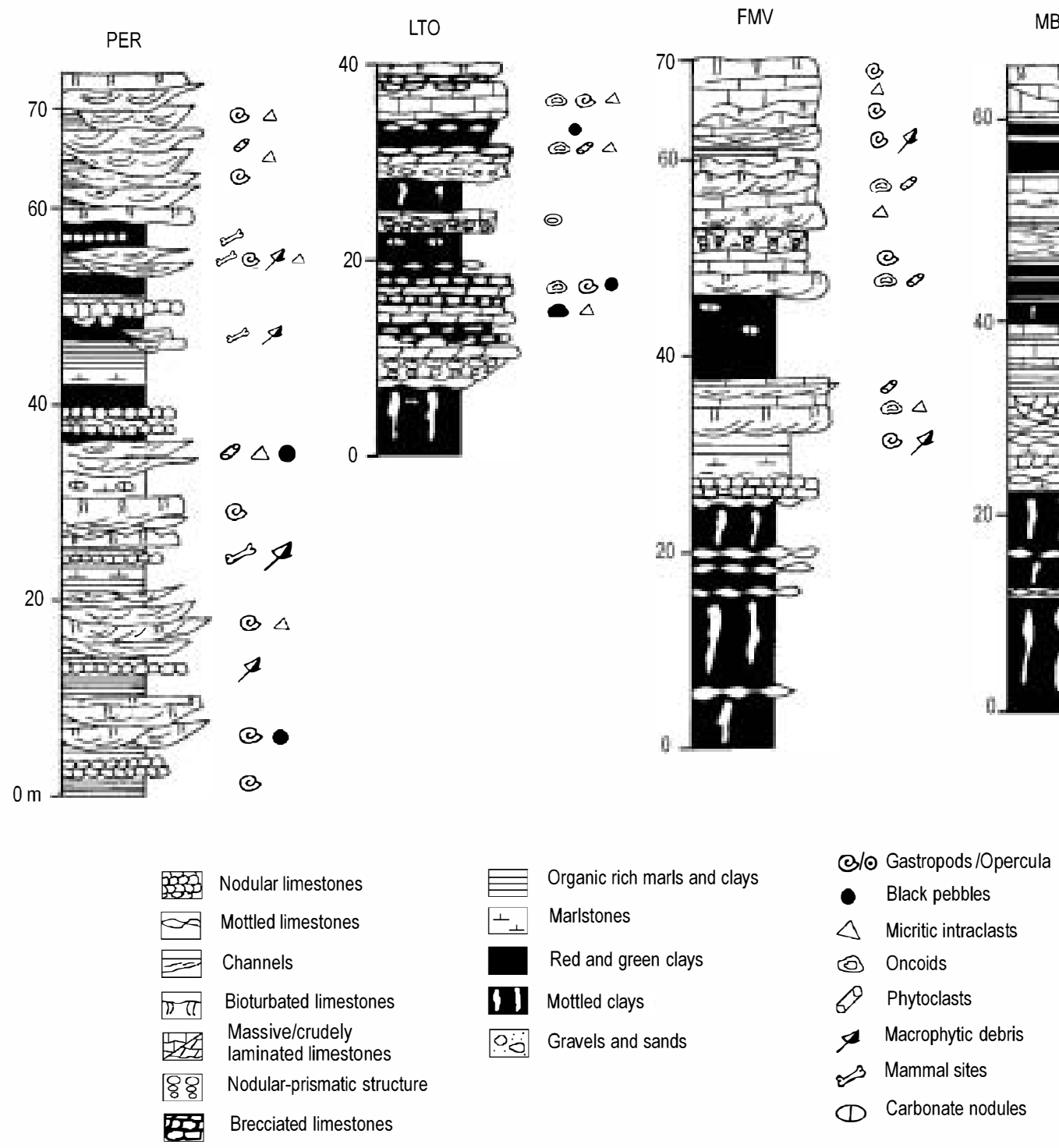

Fig. 4. Lithostratigraphic logs showing the most typical lithofacies recognised in the Miocene of the northern Teruel Graben. For location see Fig. 2. PER, Peralejos; LTO, Laguna de Tortajada; FMV, Fondo de Masada del Valle; MBR, Masía del Barbo (including the level with gastropod opercula).

Opdyke et al. (1997), who have established a precise chronology based on both mammal faunas and magnetostratigraphy. According to these authors, MN14, MN15 and MN16 zones (Ruscinian-Villafranchian) are recorded in these sediments.

This paper is mainly focused on the lowermost units (Units I and II) present in the Teruel Graben and the study concerns the palaeoenvironmental reconstruction of the stratigraphic units placing emphasis on the sedimentary response to tectonic subsidence pulses, and climatic and source rock changes throughout the Upper Miocene stages of basin evolution. 
3. General overview and distribution of the Miocene units

This work deals with the lacustrine deposits of the two lower Miocene units (Units I and II). Within each unit a clear polarity from marginal to central areas can be recognised. However, due to the geometry of the basin, the different sedimentary environments are not distributed symmetrically with the lake deposits located closer to the eastern margin. At this margin, the alluvial deposits unconformably overlie Mesozoic or Palaeogene deposits and extend up to $2.5 \mathrm{~km}$ in a ENE-WSW direction. Maximum observed thickness of the alluvial deposits of the two Miocene units is ca. $100 \mathrm{~m}$. They consist of sheet-like gravel beds that show imbrication and in some cases well developed planar cross-stratification. Towards the west, red mudstones are dominant and intercalate mottled and nodular carbonates and even gypsum beds. In the western margin, the alluvial deposits unconformably overlie Jurassic carbonates. Maximum 1a: Distal alluvial-lake margin

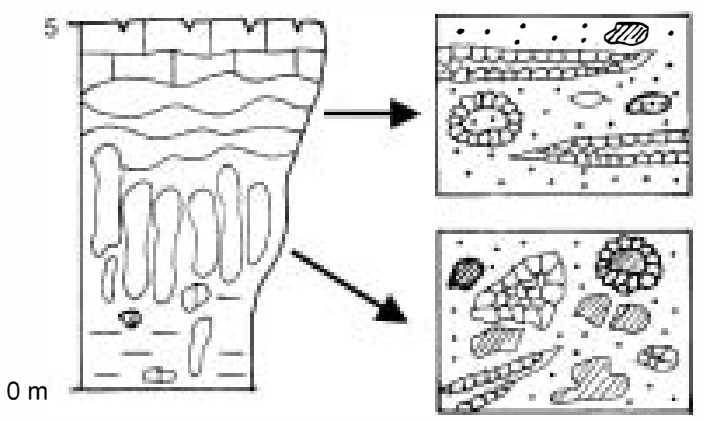

2: Carbonate fill channels

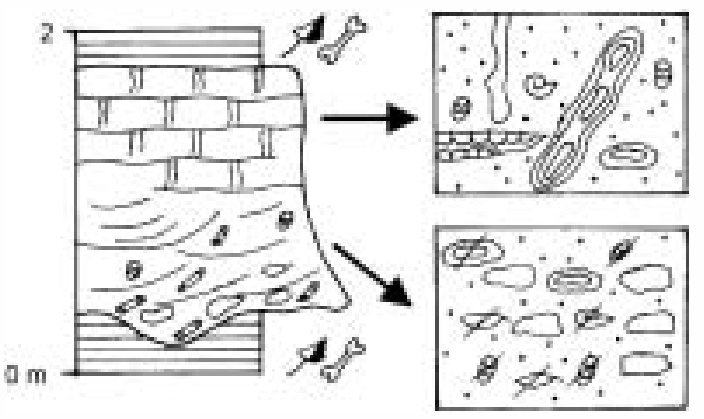

1b: Lacustrine carbonates-pedogenically modified lacustrine carbonates

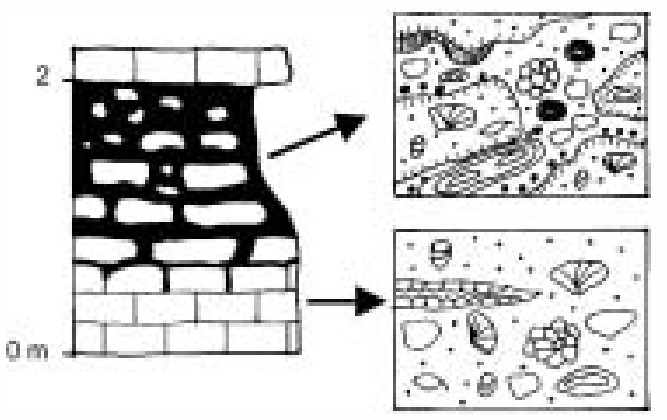

\section{3: Marshes}

c

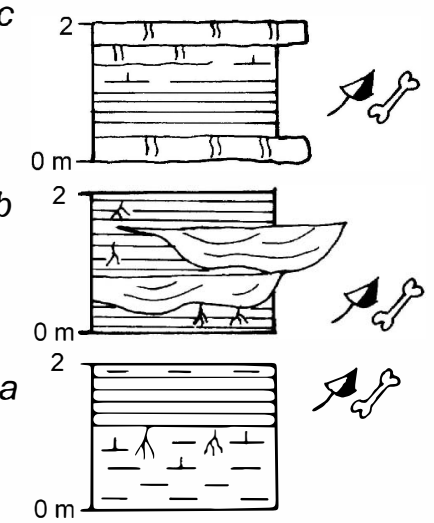

\begin{tabular}{|c|c|c|c|c|c|}
\hline 1,1 & Biomicrite beds & $\pi n$ & Bioturbated limestones & $\approx$ & Mottled limestones \\
\hline-- & Red clays & 土 & Green marls and clays & & Organic rich marlstones and clays \\
\hline 000 & $\begin{array}{l}\text { Prismatic carbonate } \\
\text { nodules within clays }\end{array}$ & & Red soil matrix & & Carbonate fill channels \\
\hline
\end{tabular}

\begin{tabular}{|c|c|}
\hline$\because \because$ & Micrite \\
\hline$\therefore$. & Vadose silt \\
\hline Exo & Desiccation cracks \\
\hline क्षेत) & Calcite spar cement \\
\hline$\theta$ & Etched detrital grains \\
\hline D의 & Limestone fragments \\
\hline$\infty$ & Pendant cements \\
\hline$E$ & Oxidised surface \\
\hline e्? & Oncoids \\
\hline 2 & Pisoids \\
\hline 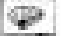 & Cyanobacterial balls \\
\hline 8 & Calcified roots \\
\hline D & Carbonate nodules \\
\hline B & Charophytes \\
\hline 8 & Gastropods \\
\hline oy & Ostracods \\
\hline 21 & Root tubes \\
\hline 9 & Macrophytic debris \\
\hline$\sigma^{3}$ & Mammal remains \\
\hline 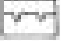 & Desiccated bed tops \\
\hline
\end{tabular}

Fig. 5. Facies associations commonly recognised in Units I and II. Petrography sketches are shown at the right of each sequence. See explanation of each sequence in the text. 
measured thickness of the gravel deposits in this western margin does not exceed $50 \mathrm{~m}$. Alluvial fan systems are not so clearly defined as in the eastern margin because most alluvial facies correspond either to small fans or to slope-scree deposits. Gravels are either clast- or matrix-supported with no recognisable sedimentary structures, although some channelised bodies are locally identified. Distally, to the east, the gravels grade into red mudstones and carbonates. The lake deposits of the two units show slightly different distributions; the carbonates of Unit II are more expansive than those of Unit I (Fig. 3).

\section{Sedimentology of the lake deposits}

Lacustrine deposits of the Miocene units have been studied all along the northern part of the Teruel Graben, from Teruel to Alfambra (Figs. 1 and 2). The main lacustrine facies that constitute the Miocene sedimentary record of the northern Teruel Graben are well represented in the lithostratigraphic logs shown in Fig. 4. The lacustrine facies and their geometric relationships with associated alluvial deposits allow the distinction of three main facies associations: carbonate lake environments; carbonate-fill channels; and organic-rich marlstones and carbonate (Fig. 5) which characterise the following sedimentary environments.

\subsection{Carbonate lake environments}

\subsubsection{Distal alluvial-lake margin}

This facies association is recognised as the gradual transition between the Red Clastic Facies and the first carbonate bed of Unit I. The deposits that characterise this transition include three different facies, from base to top: red mudstone with interbedded sandstone, typical of distal alluvial fan and/or floodplain deposits, palaeosols and palustrine mottled limestones. This sequence is up to $7 \mathrm{~m}$ thick, with gradual vertical changes between the three facies, whereas thickness of the alluvial/floodplain mudstones varies from 0.5 to $5 \mathrm{~m}$. Mudstones include green mottling, carbonate nodules and root bioturbation, which are indicative of initial stages of soil formation. More mature
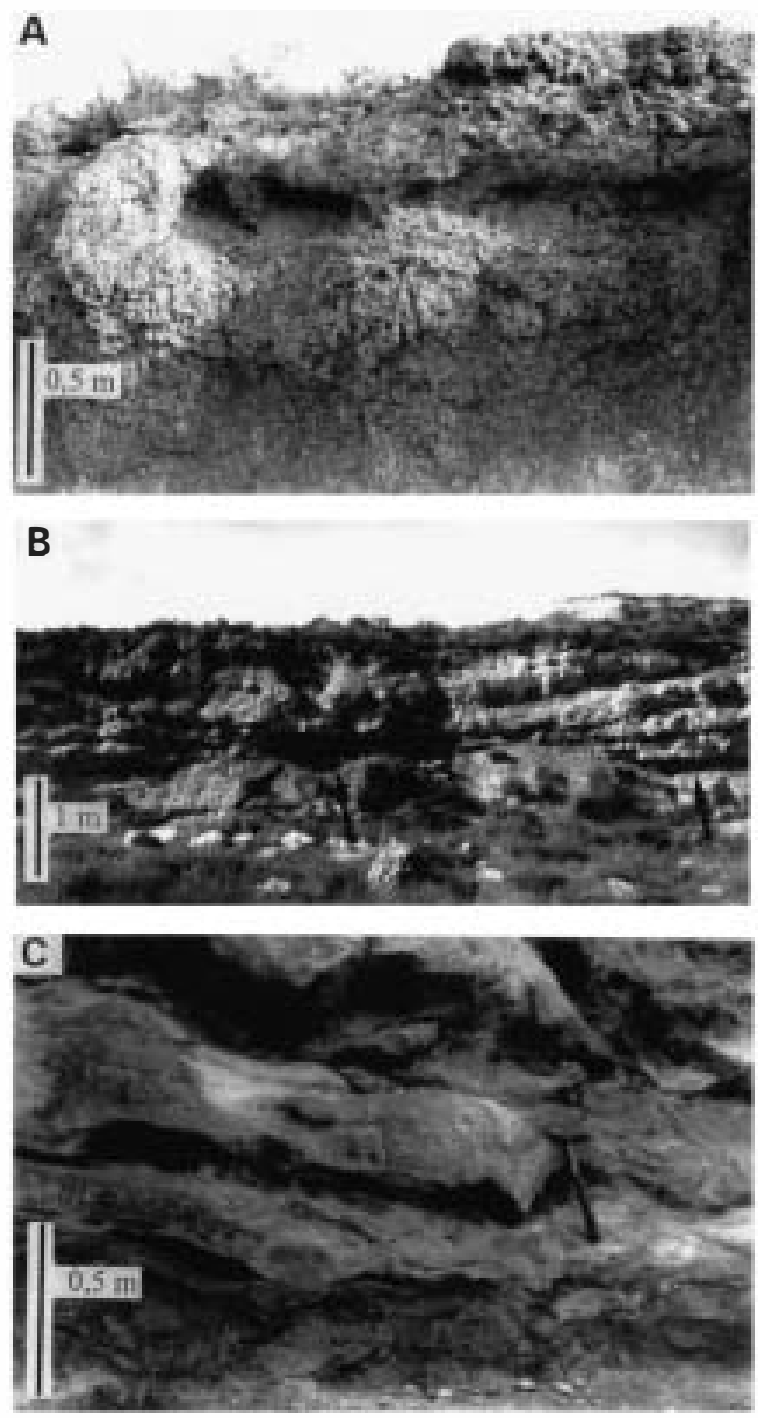

Fig. 6. (A) Sequence showing the transition from distal alluvial to lake margin environments (1a of Fig. 5). A progressive increase in the amount and size of the carbonate nodules is observed. The topmost is formed by lacustrine carbonates (Unit II, Section LTO). (B) General view carbonate fill channels associated with marshes (arrows) that develop laterally to the channels and are commonly eroded by them (arrowed) (Unit I, Peralejos area). (C) Close-up view of erosive carbonate fill channels (Unit I, Section PER).

carbonate palaeosols, stage IV of Machette (1985), develop on the red to green mudstones. Palaeosolsreach up to $4 \mathrm{~m}$ in thickness and the carbonate (calcite) content increases from the base 

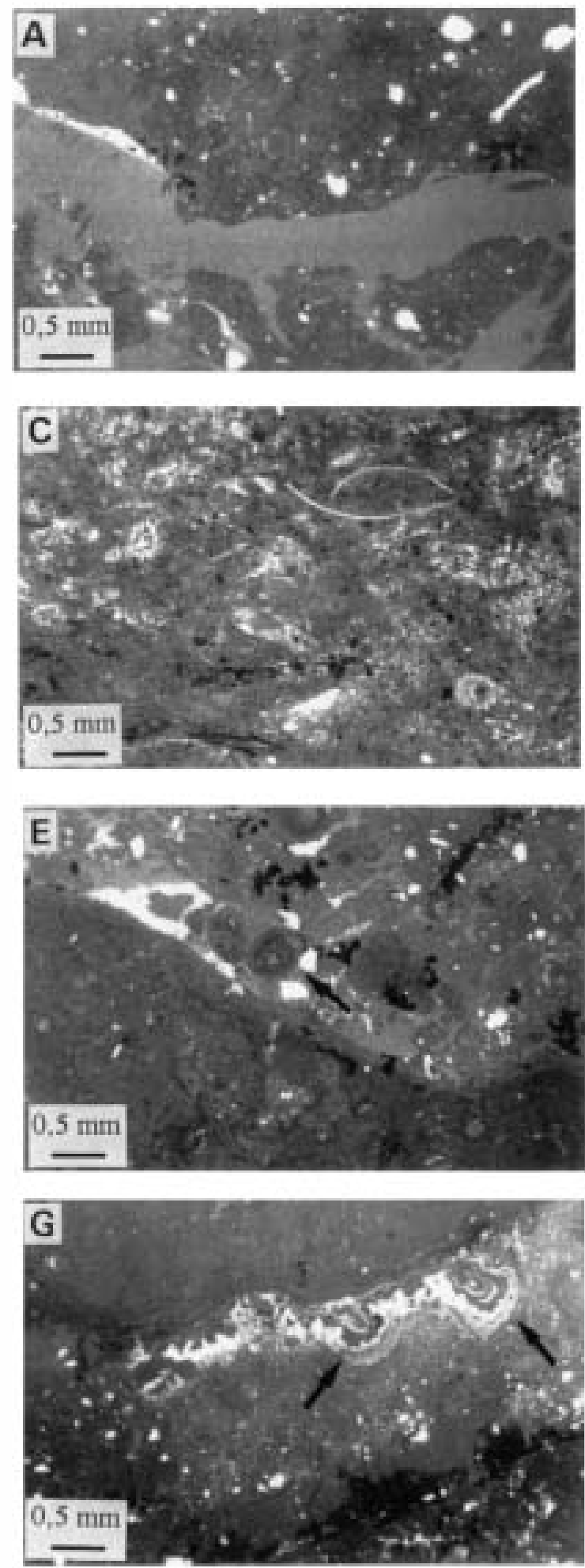
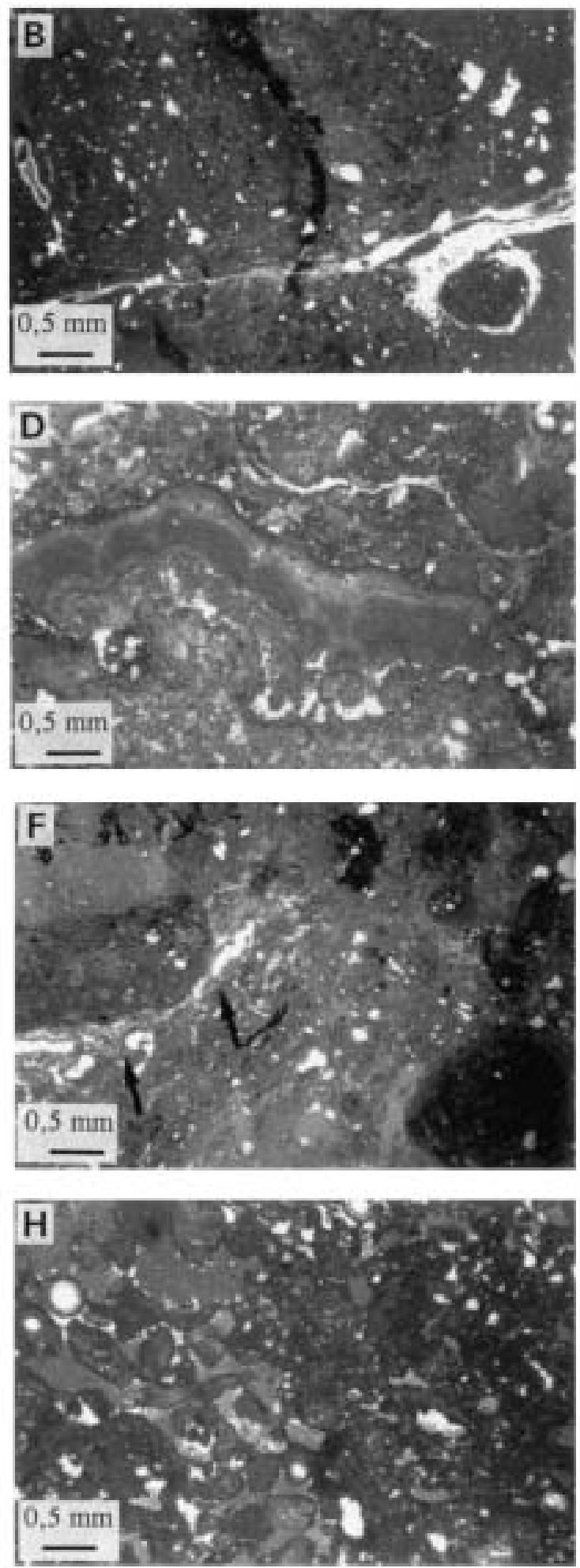
to the top. The colour varies upwards from yelloworange to beige. Macrostructure of the palaeosols changes from prismatic at the base to nodular or massive at the top [Fig. 6(A)]. Prismatic structure consists of indurated carbonate nodules arranged vertically within the mudstones; they are separated each other by films or red-orange-yellow clays, although toward the top they tend to coalesce. Nodules comprise mottled sandy micrite with horizontal and circumgranular cracks. Detrital grains included in the micrite groundmass consist of quartz and carbonate fragments that are etched and corroded by micrite and micritic filaments. Irregular micritic coatings around the detrital grains or around fragments of desiccated micrite are common. Alveolar septal structures are also recognised.

The carbonate palaeosols pass vertically into yellow to orange mottled limestones with a horizontal crack network. Thickness of the carbonate beds ranges from 0.5 to $4 \mathrm{~m}$. The limestones are micrites that contain variable amounts of oncoids, charophyte stems and gyrogonites, and ostracod shells. Alveolar septal structures, micrite filaments and mud cracks are common. Within the limestone, cracks are typically horizontal [Fig. 7(A)], several millimetres wide and decimetres long, although mean length is $5 \mathrm{~cm}$. Their morphology varies from very regular to irregular and sinuous or circumgranular [Fig. 7(B)], always maintaining horizontal geometry. Some cracks remain totally open, but others are filled partially by reworked micritic grains, vadose silt crystals [Fig. 7(A)] and fibrous vadose cements.

4.1.1.1. Interpretation. Both the vertical and lateral arrangement of the facies described reflect the transition from distal fans and/or floodplains to shallow lacustrine environments. The sequences show notable similarities with those recognised in carbonate pond deposits from the Madrid Basin (Sanz et al., 1995). The red mudstones represent the distal fan and/or the floodplain deposits. These environments being characterised by relatively low and episodic clastic sedimentation rates as indicated by the incipient pedogenesis.

Long periods of tectonic stability accounted for decreasing sedimentation rates which allowed extensive colonisation by plants and the development of more mature soils on the previous exposed mudflat/floodplain areas. The onset of carbonate accumulation within the soils took place in these periods. Precipitation was initially around roots, and resulted in the formation of carbonate nodules elongated vertically (prismatic structure). Alveolar septal structures and micritic filaments also prove the influence of organisms in carbonate precipitation (Wright, 1986; Alonso-Zarza et al., 1992). Other features, commonly observed in the carbonates, such as the corrosion of detrital grains by carbonate or mottling may form in soils by physico-chemical processes, but could also be induced by biogenic activity (e.g. drab haloes due to local reduced conditions around organic matter) (Freytet and Plaziat, 1982; Retallack, 1990) or alternatively be favoured by the presence of a surficial groundwater table. It is difficult to prove what was the dominant process, but very probably the activity of roots, extending vertically to look for water, was the starting point. Later on, rise of the groundwater table due to the vertical aggradation of the floodplain-mudflat areas (Bown and Kraus, 1987) favoured cementation of the palaeosols.

Further rise of groundwater combined with contribution from surficial run-off accounted for the establishment of a shallow water body in which carbonate precipitation was induced bio- and phys-

Fig. 7. Photomicrographs. (A) Irregular horizontal desiccation cracks showing some branches in the lower part. The cracks are filled with vadose silt. (B) Planar and circumgranular desiecation cracks filled with coarse calcite spar. (C) Biomicrites of the lower part of sequences $\mathrm{lb}$, consisting of a mixture of charophyte fragments, ostracods and mollusc shells embedded in a micrite matrix. (D) Oncoid fragment within the biomicrite. (E) Infilling of a crack within the biomicrite host rock. The crack is filled with pisoids, showing a dark inner coating and a lighter one in the outermost part (arrow), intraclasts, vadose silt, etched detrital quartz and coarse calcite spar. (F) Complex infill of a crack containing intraclasts, calcified root mats (arrow), vadose silt and quartz grains. (G) Vadose pendant cement (arrow) at the topmost of a horizontal crack. (H) Microfacies of the carbonate fill channels consisting of intraclasts and bioclasts (mostly charophyte fragments). 
ico-chemically. Biochemical precipitation is supported by the presence of oncoids, charophytes and ostracods. Purely physico-chemical processes, such as precipitation of carbonate induced by changes of temperature or degassing, could also interact with biogenic activity, but the petrography of the carbonates does not allow differentiation between these two processes. In fact, observations under a scanning electron microscope show that the micrites consist of a porous mosaic of calcite crystals, each crystal about $1 \mu \mathrm{m}$ wide. These micrite crystals are considered to be inorganic precipitates or the result of reworking of previously formed biogenic structures, for example, disagreggation of cyanobacteria micritic coatings of sheaths (Merz, 1992; Calvo et al., 2000).

The horizontal cracks are envisaged as desiccation cracks formed in stages of low water level. Homogeneity of the micrite in the lacustrine beds does not yield evidence for any number of subaerial exposure periods that affected the micrite mud. But, it is difficult to imagine a single and continued episode of deposition in a shallow lake followed by a single episode of desiccation. Thickness of the lacustrine bed and its regular distribution of the cracks along the bed indicate that this facies formed as a result of several cycles of carbonate deposition-subaerial exposure. The desiccation cracks probably started to develop and then enlarge previous bedding planes. After a period of subaerial exposure, with a rise in the water table, some of the cracks could fill initially with vadose silt and cements and later on with meteoric phreatic spar calcite. These processes are repeated in time as a response to different stages of subaerial exposure/lacustrine deposition, allowing the development of important early diagenetic processes that lead to the lithification of the lacustrine mud, without suffering any burial, but only controlled by the mobility of the shallow and emergent water table. The lithification of micrite muds seems to be a common feature of many freshwater lacustrine sequences, whose original mineralogy was a mixture of HMC and LMC (Wright et al., 1997).

\subsubsection{Lacustrine carbonates-pedogenically modified lacustrine carbonates}

This facies association comprises biomicritic limestone beds that show well-developed soils (palaeosols) at their tops. They form stacked carbonate lake-palaeosol sequences of ca. $2 \mathrm{~m}$ in thickness, the upper $0.7 \mathrm{~m}$ corresponding to the soil (Fig. 5). The biomicrite beds are tabular showing sharp contacts with the underlying carbonates whereas the contact with the soil is gradual. This facies association is widely recognised in the Tortajada section (Fig. 4, LTO). The biomicrite beds include micritic intraclasts, fragments of gastropods, charophytes, ostracods, black oncoids and black clasts [Fig. 7(C)]. Oncoids [Fig. 7(D)], black clasts and intraclasts vary from $0.5 \mathrm{~mm}$ up to $5 \mathrm{~cm}$ in size, but average size is a few millimetres across. Detrital grains and clays are very rare in the limestones. The biomicrite beds are very homogeneous from base to top, and show a network of irregular horizontal planes. In some cases these planes are seen as thin (millimetres wide) and very continuous laterally (tens of metres) cracks but in other cases, the planes show a complex infill that includes: coated grains (pisoids) [Fig. 7(E)], root mats [Fig. $7(\mathrm{~F})]$, vadose gravitational cements [Fig. 7(G)], vadose silt, intraclasts [Fig. 7(F)] and coarse calcite spar, in some cases very anhedral, and totally infilling the cavities. Whatever the case, the transition from biomicrite to the soil is gradual and irregular, typically defined by biomicrites with an irregular and intensive network of cracks that isolate biomicrite fragments [Fig. 5(1b)]. Very commonly the boundary of the biomicrite fragments is reddish or more brown that the inside due to the accumulation of iron oxides-hydroxides around organic sheaths. The soil consists of relicts of biomicrite embedded in a red matrix. Fragments of biomicrite show horizontal cracks filled by coarse spar. These cracks cannot be traced in the red matrix of the soil. The size and amount of fragments decreases from base to the top while the proportion of the soil matrix increases. Some of the fragments show irregular micritic coatings and so are considered as pisoids [Fig. 7(E)]. The pisoids show two types of coating: a red one containing more clay and a more grey micritic one. The soil matrix is red and consists of a mixture of micrite, illitic clays and iron oxides, being micrite the dominant component $(>85 \%)$. Alveolar septal structures and calcified roots are common within the red matrix [Fig. 7(F)]. 
4.1.2.1. Inter pretation. The sequence described shows a facies arrangement opposite to that of the sequences that characterise the transition from distal alluvial to lake margin environments. Sharp lower boundaries of the biomicrite beds indicate fast development of a carbonate lake on previous soil profiles. The lack of detrital grains and clays at the base of the lacustrine deposits is probably due to the fact that groundwater was the main source for water, as dominant recharge by surficial waters would result in a more significant input of detrital sediments to the lake floor. The existence of a high groundwater table due to the aggradation of the floodplain/mudflat areas, and perhaps also to slightly more humid periods, implies that tilting of the basin floor resulted in the emersion of the water table. Once lake conditions were established, carbonate sedimentation was easily produced both biogenically, as demonstrated by the presence of charophytes, oncoids and cyanobacteria bushes, and physicochemically. Infilling of the lake followed by a fall in the water level accounted for the exposure of the lacustrine carbonate, which is evidenced by the fragmentation, desiccation and root penetration of the tops of the biomicrite beds as well as by the complex features recognised within the horizontal cracks observed in the carbonates. The reddened boundary of the fragments reveals more oxidising conditions due to subaerial exposure. The infilling of cracks with vadose pendant cement and silt indicates initial and very surficial vadose conditions under which the activity of roots and other microorganisms was possible as indicated by the occurrence of coated grains and root structures within the cracks. Micrite intraclasts within the cracks were sourced from adjacent exposed biomicrites. The latest infill of cracks is spar calcite, precipitated under phreatic conditions; however, the anhedral morphology of the crystals reveals that some dissolution could have occurred later on.

Pedogenic processes are more pronounced at the uppermost part of the biomicrite beds, where the biomicrite fragments are isolated between the red soil matrix. Soil processes include dissolution and fragmentation of the biomicrite host rock, illuviation of clays, precipitation of iron oxideshydroxides, and significant biogenic activity of roots and associated microorganisms, as revealed by alveolar septal structures and calcified roots. The red coatings of the pisoids that are followed by grey ones indicate that conditions under which these features formed were initially more oxidising. Spar cements that occlude the porosity formed later when groundwater rose forming a new lake system.

\subsection{Carbonate-fill channels}

In this chapter we describe the channels that are recognised associated with the lacustrine environment. Alluvial-fan or fluvial channels will not be discussed in this paper.

This facies association comprises irregularly bedded, locally amalgamated, carbonate bodies that display clear channel geometries [Fig. 6(B)]. Thickness of the carbonate channels average $0.5 \mathrm{~m}$ and the width reaches up to $50 \mathrm{~m}$. Lower surfaces of the channels are erosive [Fig. 6(C)] on underlying carbonate channels and/or marls, while the upper surfaces are commonly planar. Bedding surfaces are in many cases affected by root bioturbation so that the upper part of the carbonate-fill channels commonly exhibits a prismatic structure. Channel fill consists mainly of oncoids, bioclasts, phytoclasts and reworked micritic grains (intraclasts) [Fig. 7(H)]. Locally, minor amounts of allochtonous grains derived from the Mesozoic formations surrounding the basin, are observed. At Masía del Barbo, channel components include large amounts of gastropod opercula (Fig. 4, Section MBR).

The internal structure of the carbonate bodies is poorly defined except for common normal grading (from medium-to fine-grained carbonate clasts), crude lamination and rare current ripples at the top of the beds. The bodies are poorly lithified.

The carbonate-fill channels and associated facies are mainly distributed along the central part of the basin forming a NNE-SSW stretching fringe which extends parallel to the basin margins. This direction is consistent with the measured palaeocurrent directions in the erosive base of the channels (from N10 to $\mathrm{N}^{\circ} \mathrm{E}$ ). The presence of carbonate channels is more conspicuous in the northern part of the basin where they occur amal- 
gamated both vertical and laterally, as observed for instance in the Peralejos section (Fig. 4, Section PER). Besides this main distributary pattern, carbonate-fill channels occur more sparsely distributed in other areas of the basin, especially to the south (Fig. 4, Section FMV). In this latter case, the channels are associated either with marls or previous limestone deposits.

\subsubsection{Interpretation}

The considerable thickness (up to $80 \mathrm{~m}$ ) of superposed carbonate-fill channels in the central part of the basin suggests that these areas behaved as a relatively more subsiding zone allowing preferential axial drainage flows within the lake system. The sedimentary features displayed by the carbonate bodies, that is, channel geometries and authochtonous origin of the channel fills, provide evidence that they formed as a result of weak to moderate energy streams that reworked previous shallow lake sediments, forming a kind of anastomosing network. A significant percentage of carbonate components formed within the channels, as demonstrated by the common presence of oncoids, charophytes and tufa fragments. The resulting picture is that of streams flowing NNESSW through a shallow lake area (Fig. 8) characterised by widely extended meadows of charophytes and other plants, such as reeds, with local marshes. This sedimentary model shows similarities with the outlined by Nickel (1982) for alluvialfan-carbonate facies of the Eocene Guarga Formation in the Spanish Pyrenees.

The maximum thickness of the stacked carbonate-fill channels indicate the location of the depocentre of the lake basin especially during the formation of Units I and II. Every individual channel may represent a subsidence pulse, or increased availability of water supply to the lake system, or lowering of the water table, or a combination of these three factors. Common upward grading from the carbonate-fill channel deposits into palustrine, root-bioturbated limestone indicates progressive decrease in energy of the streams that reworked the shallow lake area and further precipitation of lime mud probably controlled by extensive establishment of a vegetation cover.
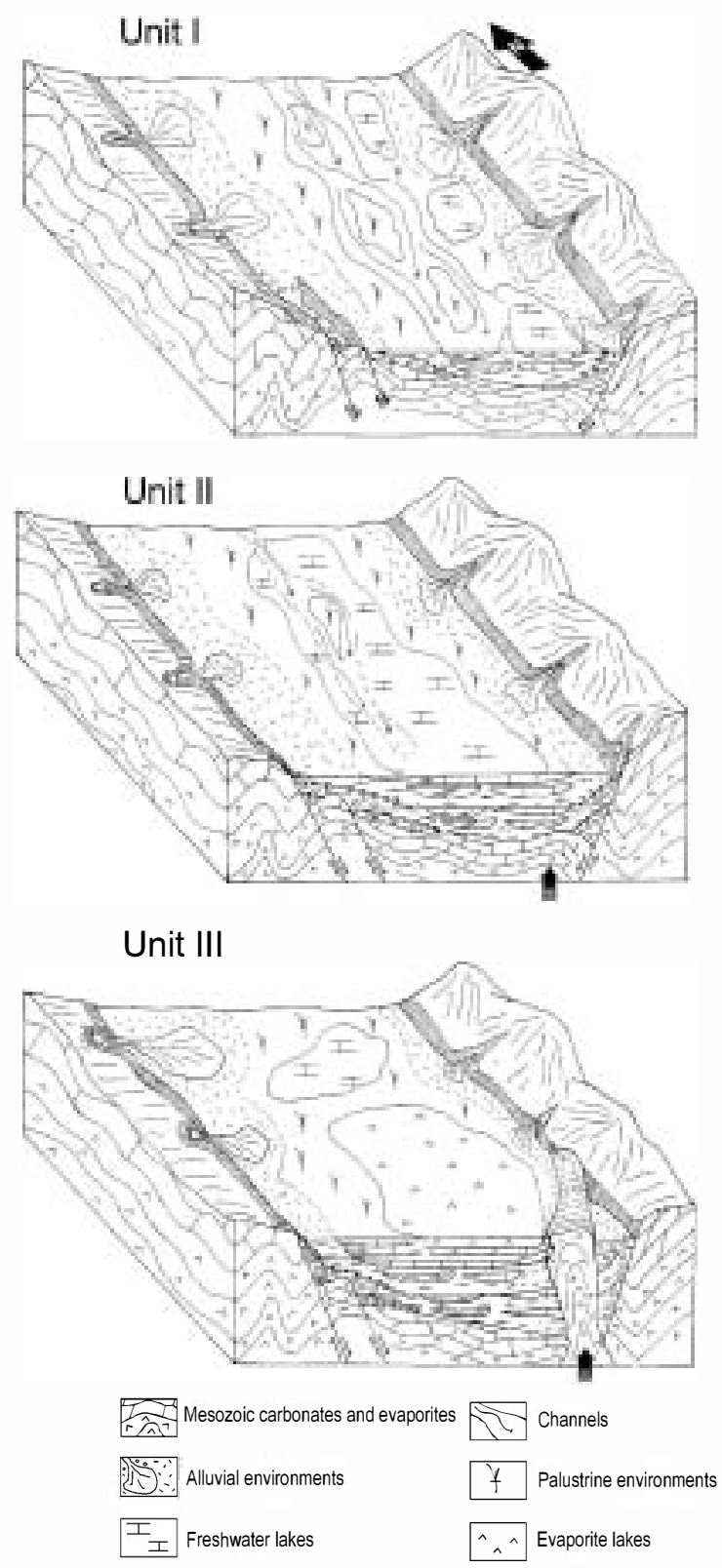

Fig. 8. Palaeogeographic reconstructions for the three Miocene units. The sketch for Unit I represents the environmental reconstruction for the upper part of the unit. The sketch for Unit II illustrates the stage of maximum expansion of the lacustrine environment at the topmost of the unit. The sketch of Unit III shows wide development of the evaporite deposits, soon after the uplift of the Triassic evaporites by diapirism. 
4.3. Organic-rich marlstones and carbonate

(marshes)

Green to black clays and marls occur in ca. $0.5 \mathrm{~m}$ thick lenses, whose lateral continuity varies from several decimetres to a few hundreds of metres. They are massive to poorly laminated and include varied amounts of gastropods, commonly flattened due to compaction, plant remains, locally some carbonate nodules, and carbonate and clay intraclasts. This facies contains most of the mammal sites of the northern Teruel Graben from which the detailed chronostratigraphy scheme of the basin is derived (Alcala, 1994; van Dam, 1997; van Dam and Weltje, 1999). Organic rich marlstones occur in three different situations:

1. Interbedded with red mudstones; in this case, the transition from red to black is gradual through a sequence of red-orange-brown to green-black marlstones and clays.

2. Associated with carbonate-fill channels; the organic-rich clays and marls occur either lateral to channels or eroded by different types of carbonate-fill channels [Fig. 6(B)]. In both cases, the transition with the underlying facies (e.g. palustrine limestones, carbonate-fill channels, etc...) is very sharp.

3. Interbedded between lacustrine-palustrine carbonates showing either sharp or gradual transitions with the carbonates.

\subsubsection{Inter pretation}

The marlstones and clays formed in shallow lake environments in which reduced conditions prevailed due to intense accumulation of organic matter. These ponded areas were probably disconnected, as supported by the discontinuous geometries of the marlstone bodies, from the adjacent wider lacustrine areas that were dominated by oxidising waters. The marshes developed in lowland areas such as: (1) floodplain/mudflat areas with low sedimentation rates; (2) abandoned channels; or (3) relatively open lacustrine areas with dominant carbonate sedimentation that were progressively isolated from the main water body.

Reducing conditions needed for the preservation of organic matter could be established throughout the whole water body, but was probably only permanent in the lake bottom, as a result combined effect of accumulation of plant debris transported by slow-flowing streams and in situ growth of plants. Oxidising conditions probably prevailed in most of the shallow water column as indicated by the presence of gastropod shells in many layers of the marsh deposits.

The marshes were fed by different mechanisms working in tandem: (1) run-off/surficial waters; the presence of clays as well as some carbonate and mud intraclasts indicate surficial reworking of either carbonate lake margins or distal alluvial fan facies; and (2) groundwater recharge could easily operate in depressed areas at the time when the phreatic level intersected the surface. Shallowhanging phreatic levels were important in the formation of these more or less isolated water bodies.

\section{Isotopes}

Petrographic criteria were followed to select samples for stable isotope analysis $(\mathrm{C}, \mathbf{O})$ in carbonates. Isotopic compositions were determined from samples representative of the three main carbonate lithofacies recognised in the basin [Fig. 9(A)]:

1. Shallow lacustrine carbonate deposits that include micrites, biomicrites, micrites with gypsum moulds and tufas consisting of encrusted charophyte stems and oncolitic limestones. Some of the biomicrites correspond to carbonate-fill channels which do not show significant petrographical differences with the lacustrine biomicrites.

2. Palustrine limestones.

3. Carbonate palaeosols developed either at the top of biomicrite beds or interbedded within red alluvial deposits.

The isotopic compositions of the studied samples (Fig. 9) cover a relatively broad range of $\delta^{13} \mathrm{C}$ values, from -7.99 to -3.22 , and a narrower range for $\delta^{18}$ values $(-7.69$ to -5.15$)$. These values are in the range of the commonly determined in freshwater lacustrine carbonates (Platt, 1989; Wright and Alonso-Zarza, 1992; Valero 
A

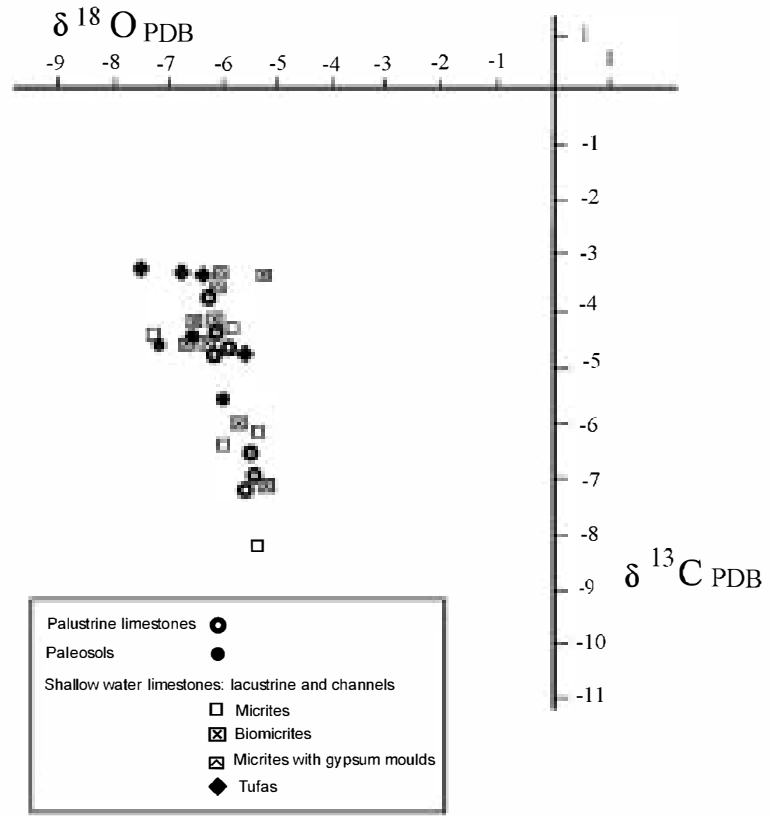

B

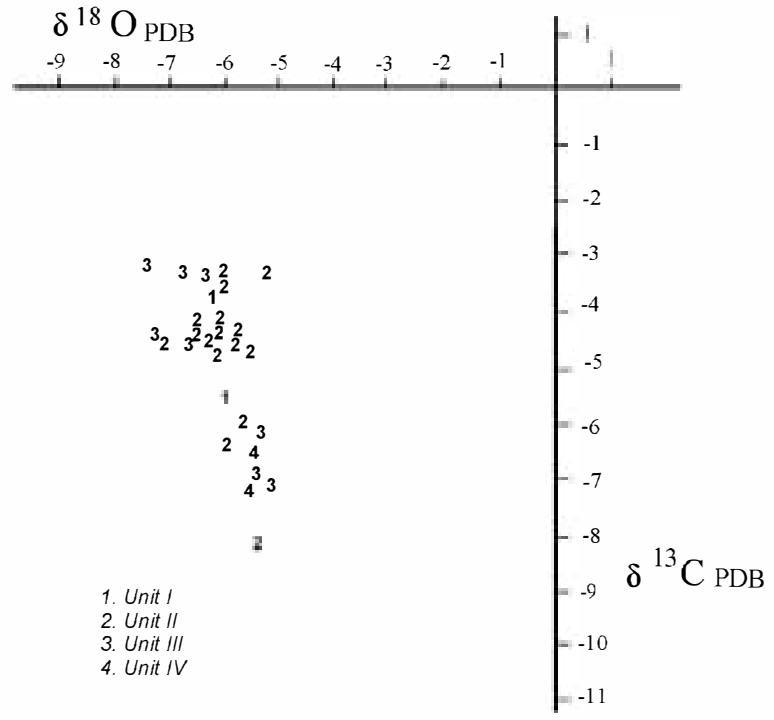

Fig. 9. Cross plot of $\delta^{18} \mathrm{O}$ versus $\delta^{13} \mathrm{C}$ for the lacustrine carbonates and palaeosols of the northern Teruel Graben. (A) Values of the different facies are shown. (B) Distribution of the isotope values in the samples from the four units.

Garcés et al., 1997). Three main features are clearly seen when analysing the overall data: (1) the covariant trend is very poor and negative $(r=$ $-0.51)$; (2) the variation of $\delta^{18} \mathrm{O}$ values is very low, only $2.54 \%$; and (3) there is no trend or differentiation between the data of the different units [Fig. 9(B)].The two former features have commonly been considered as indicative of open lake systems (Talbot, 1990; Platt, 1992; Utrilla et al., 1998) or of lakes with marked instability in their hydrology (Bellanca et al., 1992). Low variations in $\delta^{18} \mathrm{O}$ values, even considering different lithofacies types [Fig.9(A)], suggest relatively fixed lake water compositions, with the minor variations related either to minor oscillations in inflow-evaporation balance (Talbot, 1990) or to variations in the depositional subenvironments. Thus, for instance, tufas and palaeosols show relatively lighter values than lacustrine and palustrine carbonates, indicating the influence of less evolved meteoric waters in the formation of the tufas and palaeosols and relatively short residence times of waters in which lacustrine and palustrine carbonates accumulated.
Differences in $\delta^{13} \mathrm{C}$ are not easily attributable to facies types and in the study case are difficult to explain. Variations in primary productivity may cause important variations in the composition of lake-dissolved inorganic carbon (DIC), specially in short-residence and small-water bodies (Botz et al., 1988; Talbot and Kelts, 1990; Valero Garcés, 1993 ) as the studied here. However, there is not a clear relationship between environments of higher organic productivity (e.g. tufas or palaeosols) and lighter $\delta^{13} \mathrm{C}$ values. Differences in carbon isotopic composition in the lacustrine carbonates of the Teruel basin are not understood yet.

In very shallow lacustrine carbonates, early diagenetic processes can modify the isotopic signature of the primary carbonates, leading to the loss of the covariant trend (Wright et al., 1997) or to show lighter or heavier values than the primary carbonates (Arenas et al., 1999), depending on the composition of the diagenetic waters. The primary isotopic signature of the lacustrine carbonates of the Teruel Graben may have been overprinted by the early pedogenic/diagenetic processes they have undergone, although such processes should have 
resulted in a narrower range of $\delta^{13} \mathrm{C}$ values. From this point of view, although the carbonates of the Teruel Graben are not primary their isotopic values, still retain some of their primary signature.

\section{Controls on the palaeogeography and dynamics of the lake system}

Tectonics and climate are the main controls for the occurrence, distribution and dynamics of lakes. Both factors interplay to determine the morphology of the sedimentary basin, subsidence rates, hydrology, sediment supply, amongst other parameters (Hutchinson, 1957; Gierlowski-Kordesch and Kelts, 1994; De Wet et al., 1998). Source rock is an additional factor to be considered as it may determine the type of sediments that accumulate in the lake basin as well as the chemistry of the groundwaters (Gierlowski-Kordesch, 1998; Platt and Wright, 1991). The proportionate effects of climate, tectonics, sediment supply, hydrology, etc... on lake basins deposition is an on-going controversy. Several authors (Carroll and Bohacs, 1999; Strecker et al., 1999) have recently yielded conceptual frameworks to elucidate the influence of climate and tectonics on the lithologies and architecture of lake basin fills. Carroll and Bohacs (1999) concluded that there is a lack of correlation between precipitation (evaporation ratio and lake size or depth) at least in large modern lakes, which makes difficult to match lake size or water chemistry to definite trends of climatic humidity. According to these authors, the relative balance of rates of potential accommodation (mostly tectonic) with sediment + water supply (mostly climatic) is the critical factor in defining the main features of both recent and ancient basin fills. On this basis, a subdivision of lake basin into three types: (1)overfilled; (2) balance-fill; and (3) underfilled lake basins has been proposed (Carroll and Bohacs, 1999).On their side, Strecker et al. (1999) place emphasis on the stratigraphic response of lake basins to differential tectonic subsidence, particularly in extensional, low-waterbudget lacustrine rift basins. The Teruel Graben fits well these later tectonic and sedimentological conditions as the sedimentary fill of the basin throughout the Miocene mostly consisted of shallow lacustrine carbonates accumulated in an extensional tectonic regime. Main palaeoclimatic trends inferred from detailed analysis of the evolution of micromammal faunas (van Dam, 1997; van Dam and Weljte, 1999) provides a basis for the interpretation of the major stratigraphic Miocene units although chronological data are not conclusive to explain the role of climatic changes that could be represented at sedimentary mesoscales. The role of tectonism, mainly expressed as tilting of the lake floor (Strecker et al., 1999) is in our opinion well recorded by the character of the sequential arrangement of the lacustrine deposits. The influence of source rock is envisaged as a main factor controlling the facies associations present in the basin.

\subsection{Source rocks}

The Iberian Peninsula has numerous examples of lacustrine carbonate formations in basins surrounded by highlands in which carbonate rocks are dominant. For instance, the lower Cretaceous lacustrine systems of the Serranía de Cuenca central-east Spain, are closely related to karstified Jurassic massifs (Fregenal-Martínez, 1998); this is also true for the Cameros Basin (Platt, 1989). During the Tertiary, the Miocene lacustrine carbonates of the Madrid Basin (Alonso-Zarza et al., 1992) and the Upper Miocene lake systems of the Prebetic area, SE Spain (Calvo et al., 2000) offer examples of the close relationship between carbonate source rock areas and the dominant carbonate nature of the lake basin-fill.

In the Teruel Graben, the basin margins contain a variety of Mesozoic carbonate formations that undoubtedly favoured carbonate deposition in the lakes throughout the Miocene. Extensive dissolution of the highland carbonate rocks, proved by widespread occurrence of palaeokarstic features, accounted for $\mathrm{Ca}^{+2}$ and $\mathrm{HCO}_{3}^{-}$enrichment of surficial and groundwaters supply to the basin.

Tectonic movements through the evolution of a basin often result in the emplacement of new source rocks which could modify partly or totally the lithological nature of the sediments accumulated in the basin. In the Teruel Graben, this effect 


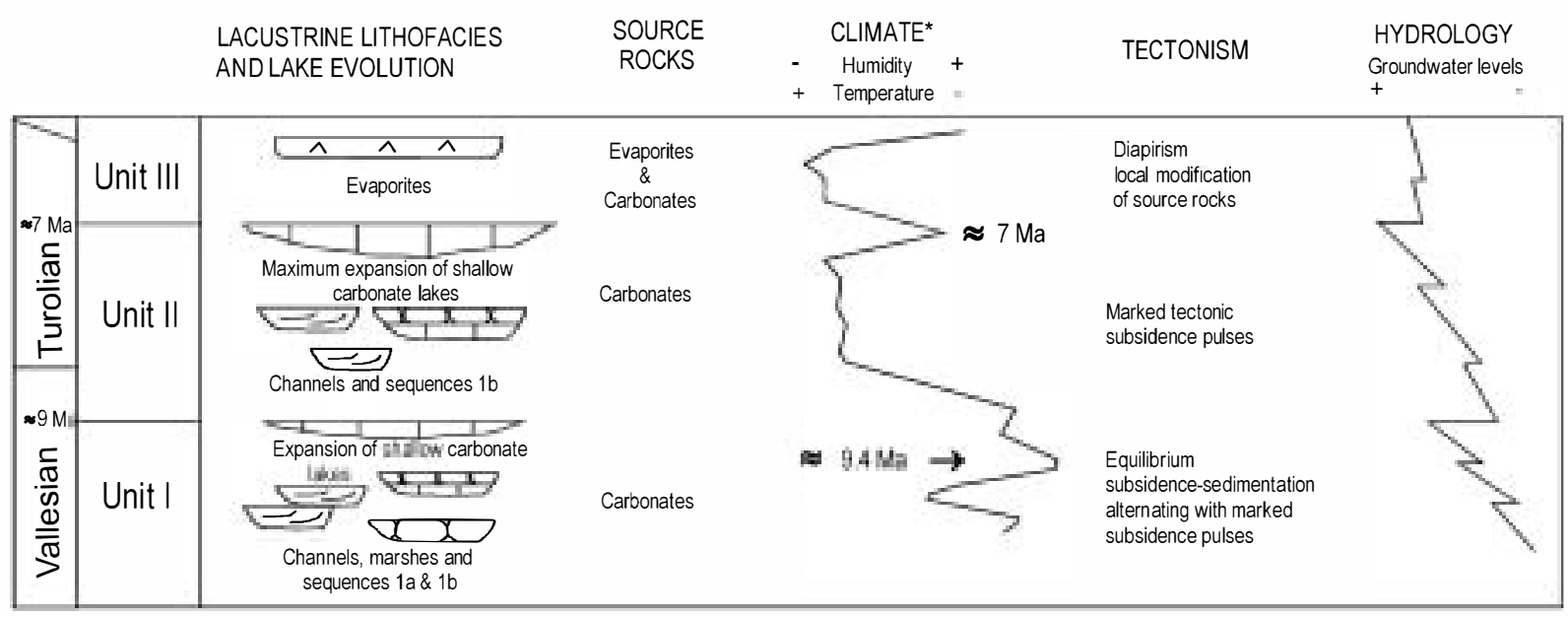

Fig. 10. Evolution of the Miocene lacustrine environments or the northern Teruel Graben as a response of source rock, climate and tectonism.

is clearly seen during the final stage of the Miocene basin infill (Unit III) (Fig. 10) when diapiric uplift at the eastern part of the basin caused extensive leaching of evaporite Triassic formations (Fig. 8; see also discussion below). As a result, widespread accumulation of gypsiferous deposits (Tortajada Formation) took place in the central part of the basin during the Middle and Upper Turolian, which is in contrast with the predominance of carbonate deposits characteristic of the underlying Miocene units.

\subsection{Climate}

Lacustrine sedimentary sequences can potentially provide a very powerful archive of palaeoenvironmental evolution in continental basins. Meaningful information about the record of past climates on local or regional scales can be obtained from specific lithofacies associations and their evolution thought time (Talbot and Kelts, 1989; Smith, 1990). Climatic influence, expressed in terms of temperature (cool versus warm) and humidity (dry versus moist), controls the input/output balance in lake systems. Carbonate lake sediments, in particular, appear to be sensitive to climatic constraints as their formation usually implies low siliciclastic input through simultaneous high dissolved load for incoming streams and groundwater feeding the lake (De Wet et al., 1998;
Gierlowski-Kordesch, 1998). The latter factor can be envisaged as a limiting factor which can rule out very arid or very humid climatic conditions for the formation of large carbonate lake deposits (Cecil, 1990). By contrast, semi-arid climates seem to be appropriate, but not exclusive, to promote carbonate deposition in lakes (Platt and Wright, 1991; Sanz et al., 1995; De Wet et al., 1998; Gierlowski-Kordesch, 1998), since present-day semi-arid lands embrace some variety of physiographic scenarios where a range of temperature and rainfall rates is recorded (Grove, 1977; Sanz et al., 1995). The appropriateness of semi-arid climatic conditions for the deposition of lake carbonates is also supported by a number of fossil lake systems such as the palustrine carbonate formations from the Upper Cretaceous-Lower Tertiary of southern France (Freytet and Plaziat, 1982) and the Miocene of the Duero Basin (Armenteros et al., 1997), amongst others.

The lacustrine facies accumulated in the northern Teruel Graben throughout the Miocene comprise mainly freshwater shallow-lake and palustrine carbonate deposits (Units I and II) developed especially during the Upper Vallesian, Lower Turolian and a part of the Middle Turolian (Fig. 3). A significant change in the sedimentary fill of the basin is recorded during the upper part of the Middle and the whole Upper Turolian (Unit III), where evaporitic gypsiferous facies are domi- 
nant in central parts of the basin. This sedimentary evolution of the stratigraphic units can be matched with the palaeoenvironmental evolutionary pattern proposed for the Miocene record of the Teruel Graben (van Dam, 1997) in order to elucidate the relative roles of climate, tectonics and source rocks in the deposition of the lake sediments.

The climatic evolution of the Teruel Graben throughout the Miocene has been inferred from the analysis of rodent palaeocommunities successions (van Dam, 1997; van Dam and Weltje, 1999). This study shows that relatively more humid and cooler climatic conditions prevailed in the basin during the Late Vallesian (with a maximum of humid-cool environmental conditions at $\sim 9.4 \mathrm{Ma}$ ), whereas the Turolian was in general characterised by more arid and warmer conditions showing a peak indicative of humid-cool environmental conditions at $\sim 7 \mathrm{Ma}$ (Fig. 10).

As inferred from the analysis of the Upper Miocene small mammal record, seasonality was a typical feature of the palaeoclimatic evolution of the region in this period. Palaeolatitude of the region during the Neogene was not much different from that of the present day (Smith et al., 1981; Anadón et al., 1989); therefore, the Teruel Graben can be regarded as a boundary area between a temperate humid and subtropical-dry climatic belt. These prevailing climatic conditions were quite favourable for the accumulation of carbonate sediments in the basin, even the presence of evaporites, when other factors such as variations in source rock and tectonism contributed additionally to their formation.

The comparison between lithofacies vertical trend and the palaeoclimatic curve deduced for the Teruel Graben (Fig. 10) shows that carbonate sedimentation took place under both moderately temperate conditions (Unit I) and more arid and warmer climate (Unit II). Stages of maximum expansion of the carbonate lakes seem to be coincident with periods of more marked cooling which could be accompanied by an increase in precipitation. More humid conditions during the accumulation of Unit I can be supported by the fact that carbonate fill channels in this unit are commonly amalgamated. And, the presence of marsh deposits is notably more common than in Unit II; this suggesting that input of incoming streams and groundwater was more permanent during the development of the former unit.

Despite the similarity of climatic conditions in which Units II and III were accumulated, a striking difference arises regarding the dominant lithologies of the two units. This provides evidence that the effect of source rocks, directly related to fast uplift by diapirism of the evaporitic Triassic rocks in some part of the basin, can actually overlap the role of climate in controlling lake deposition. Moreover, most evaporitic deposits characteristic of Unit III comprise a specific lithofacies (bioturbated gypsum) which has been described and interpreted as not indicative of strong evaporative conditions (Rodríguez-Aranda and Calvo, 1998). The latter assessment would imply that a supply of highly evaporated brines, in spite of not strictly favourable conditions for thermal evaporation, could account for the formation of considerable amounts of evaporites.

The influence of climate in the formation of mesoscale sequences, such as sequences $1 \mathrm{a}$ or $1 \mathrm{~b}$, is not easy to demonstrate due to two main reasons: (1) even if the time scale resolution for the study area, established with a mean accuracy of about 100000 years (van Dam, 1997; Garcés et al., 2000) is relatively good when compared with the timescales available for other ancient continental basins, the time resolution may be not enough to record climatically-driven depositional changes that develop at shorter time scale, thus, the role of climate in the formation of the described sequences is difficult to evaluate; and (2) the effect of tilting of the basin floor in redistributing the lake water may be more rapid than the effect of variations of humidity, then the relative roles of climate and tectonism resulting in the sequential arrangement remain uncertain. This is in agreement with findings by Colella (1988) from shallow-marine half-grabens basins.

\subsection{Tectonism and salt-related processes}

The general structural situation of the Teruel Basin is the result of the extensional tectonic regime linked to the rifting of the western Mediterranean during the Miocene (Roca, 1996). 
This tectonic setting determined the morphology of the basin, which behaved as a half-graben, and the location of the major alluvial systems (Fig. 8), and together with climate, controlled the development of the different sedimentary units and sequences. Thus, the change from Unit I to Unit II is thought to have been caused by tectonic reactivation of the eastern margin of the basin, giving place to slight deformation of the uppermost carbonates of Unit I and further progradation of the alluvial fans. Local tectonic movements, especially affecting the eastern basin margin, could have operated during the deposition of these units (Fig. 10) resulting in marked pulses of subsidence during which the created accommodation space was filled either by terrigenous or carbonate deposits. These pulses of subsidence were responsible for the lacustrine sequences that have a sharp basal contact with the underlying ones (sequences $1 \mathrm{~b}$ of Fig. 5) due to the tilting of the basin floor that caused redistribution of the lake water resulting in the emergence of the water table and the rapid formation of a shallow lake. The infilling of the shallow lakes lead to the exposure of the carbonates and further imprint by pedogenic features. This type of sequence is relatively common in other fossil lake systems, such as in the Triassic Gettysburg Formation of eastern USA (De Wet et al., 1998) or the Cretaceous of the Serranía de Cuenca where pulses of subsidence are followed by lake infill and end with soil development (Gierlowski-Kordesch et al., 1991).

The tectonic pulses could also be responsible for the NNE-SSW progradation of the carbonate fill channels that erode the other facies. Sequences with a lower member of carbonate-fill channels and a higher member of limestones displaying prismatic structures (sequence 2 of Fig. 5) may also result from episodic pulses of subsidence followed by quiet stages in which very shallow water levels allowed extensive palustrine deposition.

On the other hand, sequences of type $1 \mathrm{a}$ (Fig. 5), representative of the gradual transition from distal alluvial to lake deposits, do not seem to have been developed under such an active tectonic regime. Progressive decrease of clastic input followed by the installation of a shallow water body are easily explained by slow but continuous aggradation of the floodplain areas and subsequent rise of the water table. This sedimentary pattern could result from an equilibrium between tectonic subsidence and sedimentation which appears to have been a common situation during the deposition of Unit I (Fig. 10). Increasing humidity could also contribute significantly to the development of this type of sequences.

Normal faulting characteristic of the eastern margin in previous stages of the basin evolution (Fig. 10) was disrupted by a sudden uplift driven by diapirism of Triassic mudstones and evaporites. Tectonic uplift resulted in fracturing and folding of Units I and II giving place to development of alluvial fans and associated shallow lake deposits mainly formed of evaporites that characterise Unit III near the diapir. Thus local tectonic movements involving diapirism resulted in a rearrangement of both the distribution and nature of depositional systems in the basin. The effect of diapirism in controlling basin morphologies and types of lacustrine sedimentary sequences has been also documented by Anadón et al. (1998) in the Miocene Bicorp Basin in eastern Spain. In the Teruel Graben, the influence of evaporite formations, whether by salt dissolution (interstratal karst, mantled karst; Gustavson, 1986) or diapiric uplift has continued until recent (Gutiérrez Santolalla, 1999). This behaviour of Triassic evaporite formations must have controlled sedimentation in the basin at least since the Middle Turolian or even earlier.

\section{Conclusions}

The Miocene stratigraphic record of the Teruel Graben is composed of three main units (Units IIII) that comprise a variety of lacustrine deposits whose characteristics and vertical arrangement were controlled by the combined effect of source rock, climate and tectonism. Units I and II are formed of lacustrine carbonate facies and associated alluvial deposits. During the accumulation of these units, source rocks consisted mainly of Mesozoic carbonate formations that formed the margins of the basin. In this period (from Late 
Vallesian to the lower part of the Middle Turolian), the Teruel Graben behaved as a hydrologically open basin as deduced by facies distribution and isotope geochemistry of the carbonate sediments.

Unit I developed under a contrasting tectonic regime in which periods of sedimentation-subsidence equilibrium alternated with more marked subsidence tectonic pulses. This tectonic regime together with a general wetter and cooler climate allowed the deposition of a variety of facies associations in which two distinctive sedimentary sequences are recognised: (1) distal alluvial-lake margin sedimentary sequences developed in periods characterised by sedimentation-subsidence equilibrium that enabled slow aggradation of the floodplain/distal fan areas and subsequent rise in the water table and ponding; and(2) sequences composed of lacustrine carbonates and pedogenically-modified lacustrine carbonates that formed under a more active tectonic regime dominated by marked subsidence pulses, this allowing rapid ponding on the distal fan areas and subsequent lacustrine sedimentation, followed by intense soil development. The sedimentary evolution of these sequences may be matched with that observed in carbonate fill channel sediments deposited in adjacent lacustrine subenvironments. The incision of the channels may be also related to pulses of subsidence; further infill of the channels resulted in the shallowing of the channelised area and formation of pedoturbated limestones. Marshes were widely developed in Unit I, probably as a response to the wetter climatic conditions that prevailed during deposition of this unit.

Reactivation of normal faulting in the eastern margin of the basin caused progradation of the alluvial deposits of Unit II onto the lacustrine carbonates of Unit I. Except for the very top, Unit II was deposited under relative more arid conditions and its development was constrained by a general tectonic regime characterised by marked subsidence pulses. Under this regime sequences of lacustrine carbonates-pedogenically modified lacustrine carbonates as well as carbonate fill channels were widely developed. Formation of marshes was drastically reduced, probably because of less humid climatic conditions. A change to more humid and cooler climate during the Middle
Turolian $(\sim 7 \mathrm{Ma})$ resulted in the expansion of the lacustrine carbonates at the top of Unit II.

A change of source rocks caused by the diapiric uplift of Triassic evaporites resulted in wide deposition of lacustrine evaporites of Unit III. These evaporites were deposited under a similar climate to that which prevailed in the basin during the accumulation of Unit II (mainly formed of lacustrine carbonates) which provides evidence of the major role of source rock and tectonism controlling the sedimentation in the Teruel Graben throughout the Miocene.

\section{Acknowledgements}

The authors wish to thank Drs. Luis Alcalá and Jan van Dam for their contribution to the chronostratigraphy of the Teruel Basin. Drs. Concha Arenas and David Gómez are thanked for helpful discussions and time spent in the field. Reviews by Drs. E. Gierlowski-Kordesch, P. Freytet and P. DeDeckker notably contributed to improving the paper. The work has been supported by DGICYT Project No. PB-950114.

\section{References}

Alcalá, L., 1994. Macromamiferos neógenos de la fosa de Alfambra-Teruel. Instituto de Estudios Turolenses-Museo Nacional de Ciencias Naturales, CSIC, Teruel-Madrid.

Alonso-Zarza, A.M., Calvo, J.P., García del Cura, M.A., 1992. Palustrine sedimentation and associated features - grainification and pseudo-microkarst - in the Middle Mioene (Internnediate Unit) of the Madrid Basin, Spain. Sediment. Geol. 76, 43-61.

Alonso-Zarza, A.M., Calvo, J.P., van Dam, J., Alcalá, L., 2000. Northern Teruel Graben Neogene NE Spain. In: Gierlowski-Kordesch, E., Kelts, K. (Eds.), Lakes Trough Space and Time, AAPG Memoir. AAPG.

Anadón, P., Moissenet, E., 1996. Neogene basins in the Eastern Iberian Range. In: Friend, P.F., Dabrio, C.F. (Eds.), Tertiary Basins of Spain. The Stratigraphic Record of Crustal Kinematics. World and Regional Geology Series 6. Cambridge University Press, Cambridge, pp. 68-76.

Anadón, P., Cabrera, L., Juliá, R., Roca, E., Rosell, L., 1989. Lacustrine oil-shale basins in Tertiary grabens from NE Spain (Western European rift systems). Palaeogeogr. Palaeoclimatol. Palaeoecol. 70, 7-28.

Anadón, P., Robles, F., Roca, E., Utrilla, R., Vázquez, A., 
1998. Lacustrine sedimentation in the diapir-controlled Miocene Bicorp Basin eastern Spain. Palaeogeogr. Palaeoclimatol. Palaeoecol. 140, 217-243.

Arenas, C., Alonso-Zarza, A.M., Pardo, G., 1999. Dedolomitization and other early diagenetic proœsses in Mioœne lacustrine deposits Ebro Basin Spain. Sediment. Geol. 125, $23-45$.

Armenteros, I., Daley, B., García, E., 1997. Lacustrine and palustrine facies in the Bembridge Limestone (late Eocene Hamshire Basin) of Isle of Wight southern England. Palaeogeogr. Palaeoclimatol. Palaeoecol. 128, 111-132.

Bellanca, A., Calvo, J.P., Censi, P., Neri, R., Pozo, M., 1992. Recognition of lake-level changes in Miocene lacustrine units Madrid Basin, Spain. Evidence from facies analysis isotope geochemistry and clay mineralogy. Sediment. Geol. $76,135-153$

Botz, R., Stoffers, R., Faber, E., Tietze, K., 1988. Isotope geochemistry of carbonate sediments from lake Kivu (EastCentral Africa). Chem. Geol. 69, 299-308.

Bown, T.M., Kraus, M.J., 1987. Integration of channel and floodplain suites. I. Development sequence and lateral relations of alluvial paleosols. J. Sediment. Petrol. 57, 587-61.

Calvo, J.P., Gómez-Gras, D., Alonso-Zarza, A.M., Jímenez, S., 2000. Architecture of a bench-type carbonate margin and its relation to fluvially-dominated deltas Las Minas Basin Upper Mioene, SE Spain. J. Sediment Res. 70, 240-254.

Camoin, G., Casanova, J., Rouchy, J.M., Blanc-Valleron, M.M., Deconinck, J.F., 1997. Environmental controls on perennial and ephemeral carbonate lakes: the central palaeoAndean Basin of Bolivia during Late Cretaœous to early Tertiary times. Sediment. Geol. 113, 1-26.

Carroll, A.R., Bohacs, K.M., 1999. Stratigraphic classification of ancient lakes: balancing tectonic and climatic controls. Geology 27, 99-102

Cecil, C.B., 1990. Paleoclimate controls on stratigraphic repetition of chemical and siliciclastic rocks. Geology 18, 533-536.

Colella, A., 1988. Fault-controlled marine Gilbert-type fan deltas. Geology 16, 1031-1034.

De Wet, C., Yocum, D.A., Mora, C., 1998. Carbonate lakes in closed basins sensitive indicators of climate and tectonics an example from the Gettysburg Basin Triassic Pennsylvania USA. Role of Eustasy Climate and Tectonism in Continental Rocks. SEPM Special Publ. 59, 191-209.

Fregenal-Martínez, M.A., 1998. Análisis de la cubeta sedimentaria de Las Hoyas y su entorno paleogeográfico Cretácico Inferior de la Serranía de Cuenca Sedimentología y aspectos tafonómicos del yacimiento de Las Hoyas. PhD Thesis Tesis Doctoral (unpublished). Universidad Complutense de Madrid, Madrid.

Freytet, P., 1984. Les sédiments lacustres carbonatés et leurs transformations par émersion et pédogenèse Importance de leur identification pour les reconstitutions paéogéographiques. Bull. Centres Rech. Explor-Prod. Elf-Aquitaine 8 (1), 223-246.

Freytet, P., Plaziat, J.C., 1982. Continental carbonate sedimentation and pedogenesis - Late Cretaceous and Early
Tertiary of Southern Franee. Contr. Sediment. vol. 12. Schweizerbart, Stuttgart.

Garcés, M., Krijgsman, W., van Dam, J.A., Calvo, J.P., Alcalá, L., Alonso-Zarza, A.M., 2000. Late Miocene alluvial sediments from the Teruel area: magnetostratigraphy, magnetic susceptibility, and facies organisation. Acta Geolágica Hispánica.

Gierlowski-Kordesch, E.H., 1998. Carbonate deposition in an ephemeral siliciclastic alluvial system: Jurassic Shuttle Meadow Formation Newark Supergroup Hartford Basin USA. Palaeogeogr. Palaeoclimatol. Palaeoecol. 140, 161-184.

Gierlowski-Kordesch, E., Kelts, K., 1994. Introduction. In: Gierlowski-Kordesch, E., Kelts, K. (Eds.), Global Geological Record of Lake Basins vol. 1. University Press, Cambridge, pp. xxvii-xxxiii.

Gierlowski-Kordesch, E., Gómez Fernández, J.C., Meléndez, N., 1991. Carbonate and coal deposition in an alluvial-lacustrine setting Lower Cretaceous (Weald) in the Iberian Range (east-central Spain). In: Anadón, P., Cabrera, L., Kelts, K. (Eds.), Lacustrine Facies Analysis Spec. Publ. Int. Assoc. Sedimentol. 13, 109-125.

Godoy, A., Olivé, A., Moissenet, E., 1983. Memoria de la Hoja n 567 (Teruel). Mapa Geológico de España E. 1:50.000 ( $2^{a}$ serie). IGME

Grove, A.T., 1977. The geography of semi-arid lands. Phil. Trans. R. Soc. Lond. B 278, 457-475.

Gustavson, T.C., 1986. Geomorphic development of the Canadian River Valley, Texas Panhandle: an example of regional salt dissolution and subsidence. Geol. Soc. Am. Bull. 97, 459-472.

Gutiérrez Santolalla, F., 1999. Fenómenos de subsidencia por disolución de formaciones evaporíticas en las fosas Neógenas de Teruel y Calatayud (Cordillera Ibérica). Tesis doctoral. Universidad de Zaragoza.

Hutchinson, G.E., 1957. In: A Treatise on Limnology vol. 1, Geography Physics and Chemistry. Wiley, New York.

Machette, M.N., 1985. Calcic soils of southwestern United States. In: Weide (Eds.), Soil and Quaternary Geology of the Southwestern United States Spec. Paper 203. Geological Society of America, pp. 1-21.

Mein, P., Moissenet, E., Adrover, R., 1990. Biostratigraphie du Néogène supérieur de Teruel. Paleontología i Evolució 23, 121-139.

Merz, M.U.E., 1992. The biology of carbonate precipitation by Cyanobacteria. Facies 26, 81-102.

Moissenet, E., 1983. Aspectos de la neotectónica en la Fosa de Teruel. In: Geología de España T. II. IGME, Madrid, pp. 81-102.

Moissenet, E., 1989. Les fossés néogènes de la Chaíne Ibérique: leur évolution dans le temps. Bull. Soc. Géol. France 8 (5), 919-926.

Moissenet, E., Lindsay, E., Mein, P., Opdyke, N., Pérez-González, A., 1990. The Alfambrian: a new continental stage for the Plioene fornations of Teruel Basin. Biostratigraphy, magnetostratigraphy, referenced sections. In: IX R.C.M.N.S. Congr. Barcelona, pp. 245-247. 
Molenaar, N., DeFeyter, A.J., 1985. Carbonates associated with alluvial fans: an example from the Messinian Colombacci Fornation of the Pietrarubbia Basin, Northern Marche Italy. Sediment. Geol. 42, 1-23.

Nickel, E., 1982. Alluvial-fan-carbonate facies with evaporites, Eocene Guarga Fonnation, Southern Pyrenees, Spain. Sedimentology 29, 761-796.

Nickel, E., 1985. Carbonates in alluvial fan systems: an approach to physiography, sedimentology and diagenesis. Sediment. Geol. 42, 83-104.

Opdyke, N., Mein, P., Lindsay, E., Pérez-González, A., Moissenet, E., Norton, V.L., 1997. Continental deposits, magnetostratigraphy and vertebrate paleontology, late Neogene of Eastern Spain. Palaeogeogr. Palaeoclimatol. Palaeoecol. $133,129-148$

Platt, N.H., 1989. Lacustrine carbonates and pedogenesis: sedimentology and origin of palustrine deposits from the Early Cretaœous Rupelo Fonnation. W Cameros Basin N Spain Sedimentology 36, 665-684.

Platt, N.H., 1992. Fresh-water carbonates from the Lower Freshwater Molasse (ligocene, western Switzerland): sedimentology and stable isotopes. Sediment. Geol. 78, 81-99.

Platt, N.H., Wright, V.P., 1991. Lacustrine carbonates: facies models facies distribution and hydrocarbon aspects. In: Anadón, P., Cabrera, L., Kelts, K. (Eds.), Lacustrine facies analysis, Spec. Publ. Int. Assoc. Sedimentol. 13, 57-74.

Platt, N.H., Wright, V.P., 1992. Palustrine carbonates at the Florida Everglades: towards an exposure index for the freshwater environment. J. Sediment. Petrol. 62, 1058-1071.

Retallack, G.J., 1990. Soils of the Past. Unwin Hyman, Boston.

Roca, E., 1996. La evolución geodinámica de la Cuenca Catalano-Balear y áreas adyaœntes desde el Mesozoico hasta la Actualidad. Acta Geológica Hispánica 29, 3-25.

Rodriguez-Aranda, J.P., Calvo, J.P., 1998. Traøe fossils and rhizoliths as a tool for sedimentological and palaeoenvironmental analysis of ancient continental evaporite successions. Palaeogeogr. Palaeoclimatol. Palaeoecol. 140, 383-399.

Sanz, M.E., Alonso-Zarza, A.M., Calvo, J.P., 1995. Carbonate pond deposits related to semi-arid alluvial systems examples from the Tertiary Madrid Basin, Spain. Sedimentology 42, $437-452$

Smith, A.G., Hurley, A.M., Briden, J.C., 1981. Phanerozoic Paleocontinental Maps. Cambridge University Press, Cambridge.

Smith, M.A., 1990. Lacustrine il Shale in the geologic record. Lacustrine Exploration Case Studies and Modern Analogues. Am. Assoc. Petrol. Geol. Mem. 50, 43-60.

Soria, A.R., 1997. La sedimentación en las cuencas marginales del surco Ibérico durante el Cretácico Inferior y su entorno estructural. Tesis doctoral. Universidad de Zaragoza.

Strecker, U., Steidtmann, J.R., Smithson, S.B., 1999. A conœetual tectonostratigraphic model for seismic facies migrations in a fluvio-lacustrine extensional basin. AAPG Bull. 83, 43-61.

Talbot, M.T., 1990. A review of the palaeohydrological interpretation of carbon and oxygen isotopic ratios in primary lacustrine carbonates. Chem. Geol. 81, 261-279.

Talbot, M.T., Kelts, K., 1989. Introduction. Palaeogeogr. Palaeoclimatol. Palaeoecol. 70, 1-5.

Talbot, M.T., Kelts, K., 1990. Paleolimnological signatures from carbon and oxygen isotopic ratios in carbonates from organic-rich lacustrine sediments. Lacustrine Exploration Case Studies and Modern Analogues. Am. Assoc. Petrol. Geol. Mem. 50, 99-112.

Utrilla, R., Vázquez, A., Anadón, P., 1998. Paleohydrology of the Upper Miocene Bicorp Lake (eastern Spain) as inferred from stable isotopic data from inorganic carbonates. Sediment. Geol. 121, 191-206.

Valero Garcés, B.L., 1993. Lacustrine deposition and related volcanism in a transtensional tectonic setting Upper Stephanian-Lower Autunian in the Aragón-Béarn Basin, western Pyrenees (Spain-France). Sediment. Geol. 83, 133-160.

Valero Garœés, B.L., Gierlowski-Kordesch, E., Bragonier, W.A., 1997. Pennsylvanian continental cyclothem development no evidence of direct climatic control in the Upper Freeport Fornation (Allegheny Group) of Pennsylvannia (northern Appalachian Basin). Sediment. Geol. 109, 305-319.

van Dam, J.A., 1997. The small mammals from the Upper Miocene of the Teruel-Alfambra region (Spain): paleobiology and paleoclimatic reconstructions. Geologica Ultraiectina, Utrecht 156, 1-204.

van Dam, J.A., Weltje, G.J., 1999. Reconstruction of the Late Miocene climate of Spain using rodent palaeocommunity suecessions: an application of end-member modelling. Palaeogeogr. Palaeoclimatol. Palaeoecol. 151, 267-305.

van Dam, J.A., Alcalá, L., Alonso-Zarza, A.M., Calvo, J.P., Gareśs, M., Krijgsman, W., 2000. High-resolution late Miocene mammal biochronology and paleoecology of the Teruel-Alfambra region (NE Spain). J. Vertebrate Paleontol. (in press)

van de Weerd, A., 1976. Rodent faunas of the Mio-Pliocene continental sediments of the Teruel-Alfambra region, Spain. Utrecht Micropaleontol. Bull. Sp. Publ. 2, 1-217.

Wright, V.P., 1986. The role of fungal biomineralization in the formation of early Carboniferous soil fabrics. Sedimentology 33, 831-838

Wright, V.P., Alonso-Zarza, A.M., 1992. Significado de la composición isotópica $\left(\delta^{13} \mathrm{y} \delta^{13} \mathrm{C}\right)$ en paleosuelos carbonatados Mioeno de la Cuenca de Madrid. Geogaeta 11, 61-63.

Wright, V.P., Alonso-Zarza, A.M., Sanz, M.E., Calvo, J.P., 1997. Diagenesis of Late Mioene micritic lacustrine carbonates Madrid Basin, Spain. Sediment. Geol. 114, 81-95. 